\title{
The effects of using a lateral wedge insole on knee loading during ascending and descending stairs
}

\author{
Amneh Alshawabka, Richard Jones*, Sarah Tyson \\ From 3rd Congress of the International Foot and Ankle Biomechanics Community \\ Sydney, Australia. 11-13 April 2012
}

\section{Background}

Stair climbing demands, as compared to walking level, a greater range of motion in the lower extremity accompanied by about six times more load on knee joint [1]. Consequently, pain while climbing stairs is the first complaint in patients with knee osteoarthritis (OA) [2]. The use of lateral wedge insoles aims to decrease medial knee compartment loading by reducing the peak external knee adduction moment (EKAM) during walking [4]. The purpose of this study is to assess the biomechanical effects of wearing lateral wedge insoles on EKAM during stair climbing in elders with and without knee OA.

\section{Methods}

Thirty healthy subjects ( 21 females, 9 males; age (45.7 \pm 5.6 years $)$ ) and eight patients with mild knee OA (5 females, 3 males; age $(47.3 \pm 3)$ ) participated in the study. Subjects performed five trials of step-over-step stairs ascent and descent. Two conditions were investigated: (a) control (Standard shoe) (b) 5 degrees Salford Insole lateral wedge (LW) insoles. Kinematic and kinetic data were collected for the lower extremity using a motion capture system $\left(\mathrm{QTM}^{\mathrm{Tm}}\right)$ and two force plates (AMTI force platform stairway). Repeated measures ANOVA and Friedman's ANOVA were used for statistical analysis.

\section{Results}

During ascending stairs, LW significantly reduced the EKAM in early stance $(\mathrm{p}<.05)$ and the knee adduction angular impulse (KAAI) $(\mathrm{p}<.05)$. Similarly, the EKAM and KAAI had been significantly reduced $(\mathrm{p}<.05)$ while wearing LW during descending stairs. Both groups had significantly greater degree of subtalar eversion with LW than in the control condition (Table 1).

\section{Conclusions}

Lateral wedge insoles consistently reduced the overall magnitude of EKAM during ascending and descending

Table 1 1st EKAM peak, KAAI and Subtalar eversion angle results for healthy and OA Subjects during ascending (AS) and descending (DS) stairs.

\begin{tabular}{|c|c|c|c|c|c|}
\hline \multirow[t]{2}{*}{ Parameters } & & \multicolumn{2}{|l|}{ Mean $\pm(S D)$} & \multicolumn{2}{|l|}{ Mean $\pm(S D)$} \\
\hline & & Control (Healthy) & LW (Healthy) & Control (OA) & LW (OA) \\
\hline \multirow[t]{2}{*}{$1^{\text {st }}$ peak EKAM $(\mathrm{Nm} / \mathrm{Kg})$} & AS & $.385(.15)$ & $.357(.14)$ & $.394(.13)$ & $.366(.12)$ \\
\hline & DS & $.408(.11)$ & $.388(.10)$ & $.364(.06)$ & $.334(.05)$ \\
\hline \multirow[t]{2}{*}{$\mathrm{KAAl}(\mathrm{Nm} / \mathrm{Kg} / \mathrm{s})$} & AS & $.228(.15)$ & $.207(.14)$ & $.189(.06)$ & $.174(.06)$ \\
\hline & DS & $.228(.08)$ & $.212(.08)$ & $.204(.04)$ & $.186(.04)$ \\
\hline \multirow[t]{2}{*}{ Subtalar peak eversion (degrees) } & AS & $-5.71(2.4)$ & $-6.1(2.9)$ & $-4.41(.62)$ & $-4.82(.70)$ \\
\hline & DS & $-6.36(2.3)$ & $-7.06(2.5)$ & $-4.42(1.2)$ & $-5.11(1.5)$ \\
\hline
\end{tabular}

Centre for Health Sciences Research, University of Salford, Salford, Greater

Manchester, M6 6PU, UK 
stairs which has been strongly correlated to decreasing medial compartment loading at the knee joint. Thus, these results give the first indication that that lateral wedge insoles may be useful in decreasing pain levels for patients with knee OA during stair climbing. Further long-term studies are warranted.

Published: 10 April 2012

\section{References}

1. Andriacchi TP, et al: A study of lower-limb mechanics during stairclimbing. The Journal of Bone and Joint Surgery 1980, 62(5):749.

2. Costigan PA, Deluzio KJ, Wyss UP: Knee and hip kinetics during normal stair climbing. Gait \& posture 2002, 16(1):31-37.

3. Arden NK, et al: Osteoarthritis and risk of falls, rates of bone loss, and osteoporotic fractures. Arthritis \& Rheumatism 1999, 42(7):1378-1385.

4. Jones RK, et al: Does increased loading occur on the contralateral side in medial knee osteoarthritis and what impact do lateral wedges have on this? Osteoarthritis Cartilage 2011, Suppl 1: S176.

Cite this article as: Alshawabka et al:: The effects of using a lateral wedge insole on knee loading during ascending and descending stairs. Journal of Foot and Ankle Research 2012 5(Suppl 1):P11.

\section{Submit your next manuscript to BioMed Central} and take full advantage of:

- Convenient online submission

- Thorough peer review

- No space constraints or color figure charges

- Immediate publication on acceptance

- Inclusion in PubMed, CAS, Scopus and Google Scholar

- Research which is freely available for redistribution

Submit your manuscript at www.biomedcentral.com/submit 